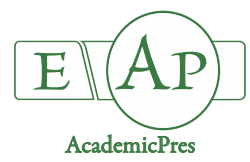

\title{
Callus Induction in Baru (Dipteryx alata Vog.) Explants
}

\author{
Rodrigo Kelson S. REZENDE ${ }^{1}$, Ana Maria N. SCOTON ${ }^{1}$, \\ Maílson V. JESUS ${ }^{1 *}$, Zeva V. PEREIRA², Fernanda PINTO ${ }^{2}$ \\ ${ }^{1}$ Federal University of Grande Dourados, Faculty of Agrarian Sciences, Highway Dourados - Itahum, Km 12 - University City, \\ mailbox 364 -Zip Code 79804-970,Dourados, MS, Brazil; rkelson@ufgd.edu.br; anamaria_scoton@hotmail.com; \\ mvjagro@gmail.com (*correspondingauthor) \\ ${ }^{2}$ Federal University of Grande Dourados, Faculty of Biological and Environmental Sciences, Highway Dourados - Itahum, Km 12 - University \\ City, mailbox 364 -Zip Code 79804-970,Dourados, MS, Brazil; zefapereira@ufgd.edu.br; fernandakozlowskipinto@gmail.com
}

\begin{abstract}
Baru (Dipteryx alata Vog.) is a species with great economic and environmental potential; it has popular acceptance, besides being a very productive species. Alternative propagation methods are important for species maintenance and exploration. Thus, micropropagation emerged as an alternative technique, providing genetic stability and the production of a large number of seedlings. The aim of the present investigation was to develop a callus induction protocol for in vitro baru explants. The tested explants were nodal, internodal and foliar segments. The explants were disinfected for 30 seconds in $70 \%$ alcohol (v/v) and 2 minutes in sodium hypochlorite (1.25\% active chlorine). This was followed by triple washing. The inoculation was carried out in test tubes containing $15 \mathrm{~mL}$ MS medium $\left(30 \mathrm{~g} \mathrm{~L}^{-1}\right.$ sucrose, $6 \mathrm{~g} \mathrm{~L}^{-1}$ agar and $100 \mathrm{mg} \mathrm{L}^{-1}$ ascorbic acid) supplemented with $2.0 \mathrm{mg} \mathrm{L}^{-1}$ naphthalene acetic acid (NAA). The solution also contained $0.0,2.5$ or $5.0 \mathrm{mg} \mathrm{L}^{-1}$ of 6 benzylaminopurine (BAP) with the $\mathrm{pH}$ adjusted to 5.8. In the incubation phase, the explants were cultured for seven days in the dark and then subjected to a photoperiod of 16 hours $\left(43 \mu \mathrm{mol} \mathrm{m} \mathrm{m}^{-1}\right)$ at $25 \pm 2{ }^{\circ} \mathrm{C}$. The treatments were studied with 2.5 , 5.0, 7.5 or $10.0 \mathrm{mg} \mathrm{L}^{-1} \mathrm{BAP}$ additions to the MS. Callus formation, contamination and oxidation evaluations were undertaken. The results obtained when using $2.0 \mathrm{mg} \mathrm{L}^{-1} \mathrm{NAA}$ concluded that such a treatment should be used to induce callogenesis from nodal explants, while for the tested baru leaf explants, the best results for callus formation were given by the combination of 2.0 $\mathrm{mg} \mathrm{L}^{-1} \mathrm{NAA}$ with $2.5 \mathrm{mg} \mathrm{L}^{-1}$ of BAP to.
\end{abstract}

Keywords: Cerrado; Dipteryx alata Vog.; micropropagation; plant growth regulators

\section{Introduction}

The Cerrado is the second largest Brazilian biome. It covers $22 \%$ of the national territory, has a wide diversity of environments, whereas fauna and flora diversity are high. The fruit species are particularly important. They have numerous uses, but little is known about them and many have not been studied or exploited (Mendonça et al., 2008).

Among these species, baru (Dipteryx alata Vog.), which belongs to the family Fabaceae, subfam. Faboideae, is thought to have great economic and environmental potential because it has many diverse uses. Its fruits and seeds can be used in human (fresh or processed) and animal diet. The fruit has high crude protein $(29.59 \%)$, ethereal extract $(40.27 \%)$ and fiber $(19.04 \%)$ contents and is a source of minerals (zinc, iron, and calcium). The seeds are used as an antirheumatic treatment and protect against oxidative stress (Lorenzi 1992; Lemos et al., 2012; Fetzer et al., 2018).
Pott and Pott (2003) highlighted the destruction of these remarkable food resources caused by negative anthropic actions. A consequence of this is that the demand for information on native plants has increased, so that forest conservation and replenishment can be improved. Arakaki et al. (2009) reported that anthropic disturbance can be prevented, so that communities can find sustainable production solutions that do not compromise the biome. They suggest that Agroforestry System (AFS) programs could be an alternative, because they integrate rural areas, and include baru in their portfolio of plants as an example of a native species that produces quality wood.

Pott and Pott (2003) pointed out that baru could be seen as a supplier species or as a component of a consortium or system, because it can potentially produce fruits, wood, medicinal products and forage. It can also improve apiculture. Candil et al. (2007) concluded that if there were incentives and the production was viable, baru could contribute to rural tourism by enhancing the

Received: 06 Sep 2018. Received in revised form: 30 Nov 2018. Accepted: 03 Dec 2018. Published online: 03 Dec 2018. 
characterization of products intrinsic to local communities, which would increase local land and property values and improve sustainability.

According to Lorenzi (1992), the production of seedlings (mostly seminal propagated) is a limiting factor on the cultivation of this species, despite the high (90\%) germination rate. This means that there is a long juvenile period. There is also concern about the genetic variability of the progenies with regards to the agronomic traits that are important for commercial fruit growing. Vieira et al. (2016) suggested that it is necessary to prioritize activities, such as germplasm collection, characterization of genetic variability, agronomic evaluation of the native species, as well their in situ and ex situ conservation, in order to preserve these species, most of which are threatened by the expansion of agriculture in the Cerrado region.

Micropropagation is an alternative method for plant regeneration, as there are efficient protocols provided for vegetative propagation. Even more, it needs to be carried out under controlled conditions, so that genetically and physiologically uniform seedlings that meet sanitary quality standards can be produced (Eldessoky et al., 2014).

The in vitro development of baru (Dipteryx alata Vog.) has already been studied. Araruna et al. (2017) evaluated the effect of different salt concentrations in the culture media. During the initial development of baru seedlings, the stem tips developed better in the MS culture medium (Murashige and Skoog, 1962), when no salts were added, compared to different concentrations of salt. Also, the seedliong developed better when they were cultivated on MS media rather than WPM medium (Lloyd and McCown, 1980). Silva et al. (2016) tested various activated carbon concentrations in different culture media and found out that the MS medium plus $3.0 \mathrm{~g} \mathrm{~L}^{-1}$ of activated carbon could potentially improve in vitro baru establishment.

The objective of the present study was to develop a callus induction protocol for in vitro foliar, nodal and internodal baru explants, by comparing different concentrations and combinations of naphthalene acetic acid (NAA) and 6benzylaminopurine (BAP).

\section{Materials and Methods}

Description of the study site

The experiment was conducted at the Plant Biotechnology Laboratory of the Center for Biotechnology and Genetic Improvement of Sugarcane, located at the Faculty of Agricultural Sciences, Federal University of Grande Dourados, DouradosMS.
The experiment had two phases; during the first phase the different explant types and growth regulators were investigated, and during the second phase the in vitro protocol was adapted so that it could be used with leaf segments.

\section{First phase of the experiment}

Young plants, derived from in vitro germination of baru seeds, were placed in flasks containing $50 \mathrm{~mL}$ of MS medium, and $6 \mathrm{~g} \mathrm{~L}^{-1}$ of agar, but no sucrose, and these were used as matrices. The flasks were kept in a growth room at $25 \pm 2{ }^{\circ} \mathrm{C}$ and with a photoperiod of 16 hours $\left(43 \mu \mathrm{mol} \mathrm{m}^{-2} \mathrm{~s}^{-1}\right)$ light.

Twenty-one days after germination (DAG) in the horizontal flow chamber, the plants underwent disinfection in alcohol $70 \%$ $(\mathrm{v} / \mathrm{v})$ followed by 2 minutes in sodium hypochlorite $(1.25 \%$ active chlorine) with three drops of neutral detergent. Then, they were triple washed with distilled water.

The seedlings were sectioned using a scalpel, to obtain three types of explants: nodal and internodal segments, inoculated in the horizontal position, and leaf segments that were approximately $1 \mathrm{~cm}^{2}$ in size.

The inoculation of the explants was carried out in test tubes containing $15 \mathrm{ml} \mathrm{MS}$ medium $\left(30 \mathrm{~g} \mathrm{~L}^{-1}\right.$ sucrose, $6 \mathrm{~g} \mathrm{~L}^{-1}$ agar and $100 \mathrm{mg} \mathrm{L}^{-1}$ ascorbic acid) supplemented with two regulators, which were $2.0 \mathrm{mg} \mathrm{L}^{-1}$ of naphthalene-acetic acid (NAA) and $0.0,2.5$ or $5.0 \mathrm{mg} \mathrm{L}^{-1}$ 6-benzylaminopurine (BAP). The $\mathrm{pH}$ was adjusted to 5.8 before the samples were autoclaved at $121^{\circ} \mathrm{C}$ for 20 minutes.

During the incubation phase, the material was submitted to seven days of darkness and then transferred to a photoperiod of 16 hours $\left(43 \mu \mathrm{mol} \mathrm{m}^{-2} \mathrm{~s}^{-1}\right)$ light, at $25 \pm 2{ }^{\circ} \mathrm{C}$. The percentage of callus formation, contamination and oxidation were evaluated on a weekly basis until their cessation. The regulator combinations were randomly distributed between explant types (Table 1).

\section{Second phase of the experiment}

The second phase only used leaf segments, but the same methodology used in phase one was adopted, except that the growth regulator concentrations were altered. Therefore, inoculation of the explants was carried out test tubes containing $15 \mathrm{~mL}$ of MS medium $\left(30 \mathrm{gL}^{-1}\right.$ sucrose, $6 \mathrm{~g} \mathrm{~L}^{-1}$ agar and $100 \mathrm{mg}$ $\mathrm{L}^{-1}$ ascorbic acid) supplemented with $2.0 \mathrm{mg} \mathrm{L}^{-1}$ of NAA, combined with $0.0,2.5 ; 5.0,7.5$ or $10.0 \mathrm{mgL}^{-1}$ of BAP (Table 2).

\section{Statistical procedures}

A completely randomized design was used in both phases of the experiment. The experimental data were submitted to analysis of variance followed by Tukey's test at the $\mathrm{P}<0.05$ probability level. The SISVAR statistical program (Ferreira, 2011) was used for the analyses.

Table 1. Treatments used in phase one of baru (Dipteryx alata Vog.) callogenesis induction experiment

\begin{tabular}{ccccc}
\hline Treatment & NAA $\left(\mathbf{m g ~ L}^{-\mathbf{1}}\right)$ & BAP $\left(\mathbf{m g ~ L}^{-\mathbf{1}}\right)$ & Explant & No. of replicates \\
\hline T1 & 2.0 & 0.0 & Nodal segment & 20 \\
T2 & 2.0 & 2.5 & Nodal segment & 20 \\
T3 & 2.0 & Nodal segment & 20 \\
T4 & 2.0 & 0.0 & Internodal segment & 20 \\
T5 & 2.0 & Internodal segment & 20 \\
T6 & 2.5 & Internodal segment & 20 \\
T7 & 2.0 & Leaf segment & 20 \\
T8 & 2.0 & 0.0 & Leaf segment & 20 \\
T9 & 2.0 & Leaf segment & 20 \\
\hline
\end{tabular}


Table 2. Treatments used in phase two of the baru (Dipteryx alata Vog.) callogenesis induction experiment

\begin{tabular}{ccccc}
\hline Treatment & NAA $\left(\mathbf{m g ~ L}^{-1}\right)$ & BAP $\left(\mathbf{m g ~ L}^{-1}\right)$ & Explant & No. of replicates \\
\hline T1 & 2.0 & 2.5 & Leaf segment & 20 \\
T2 & 2.0 & 5.0 & Leaf segment & 20 \\
T3 & 2.0 & 7.5 & Leaf segment & 20 \\
T4 & 2.0 & 10.0 & Leaf segment & 20 \\
\hline
\end{tabular}

\section{Results}

\section{First phase}

Twenty days after inoculation, the highest callogenesis percentage occurred in the nodal explants treatments that contained $2.0 \mathrm{mg} \mathrm{L}^{-1} \mathrm{NAA}$ and $2.0 \mathrm{mg} \mathrm{L}^{-1}$ of NAA with 2.5 $\mathrm{mg} \mathrm{L}^{-1}$ BAP (Fig. 1). Phenolic oxidation did not occur in any of the treatments. There were differences in explant contamination between the treatments and between the different types of explants. The lowest contamination percentages occurred on the leaf segments and the highest on the uninodal explants (Fig. 2).

\section{Second phase}

The results for the leaf segments in the first phase showed that they had the lowest callus percentages. Therefore, the second phase objective was to adapt the protocol for leaf segments. The highest callus percentage for the leaf explants was observed during the same period as it was during the first phase (20 DAI) when $2.0 \mathrm{mg} \mathrm{L}^{-1} \mathrm{NAA}$ was combined with $2.5 \mathrm{mg} \mathrm{L}^{-1}$ BAP. Interestingly, oxidation of the explants was higher in the treatments where $2.0 \mathrm{mg}$ $\mathrm{L}^{-1} \mathrm{NAA}$ was combined with $7.5 \mathrm{mg} \mathrm{L}^{-1}$ or with $10.0 \mathrm{mg} \mathrm{L}^{-1}$ BAP, but there was no contamination. The results are shown in Fig. 3.

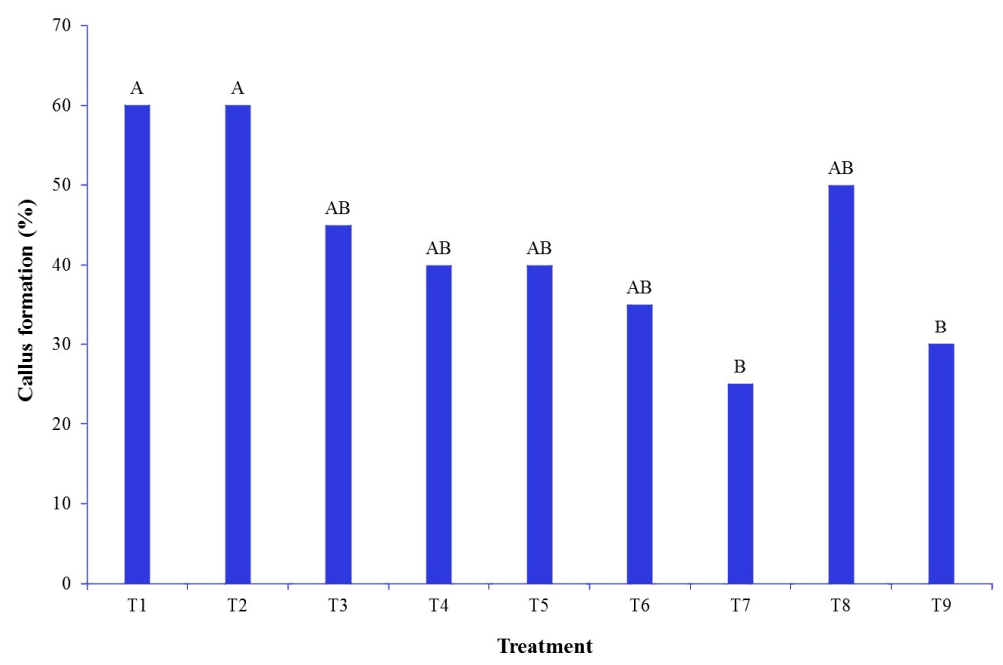

Fig. 1. Callus formation percentages for different types of baru explants cultured in vitro at different concentrations and combinations of NAA and BAP. Means followed by the same letter were not significantly different according to Tukey's test at P $<0.05$. Treatments $\mathrm{T} 1$ to $\mathrm{T} 9$ are explained in Table 1

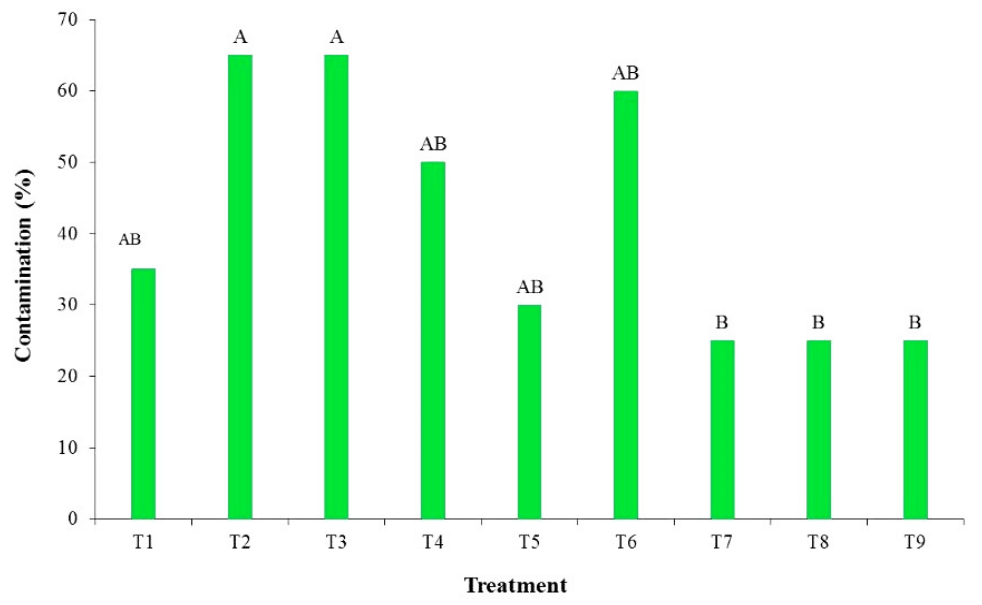

Fig. 2. Percentage contamination of the baru explants cultivated in vitro at different concentrations and combinations of NAA and BAP. Means followed by the same letter do not differ according to Tukey's test at $\mathrm{P}<0.05$. Treatments T1 to T9 are explained in Table 1 


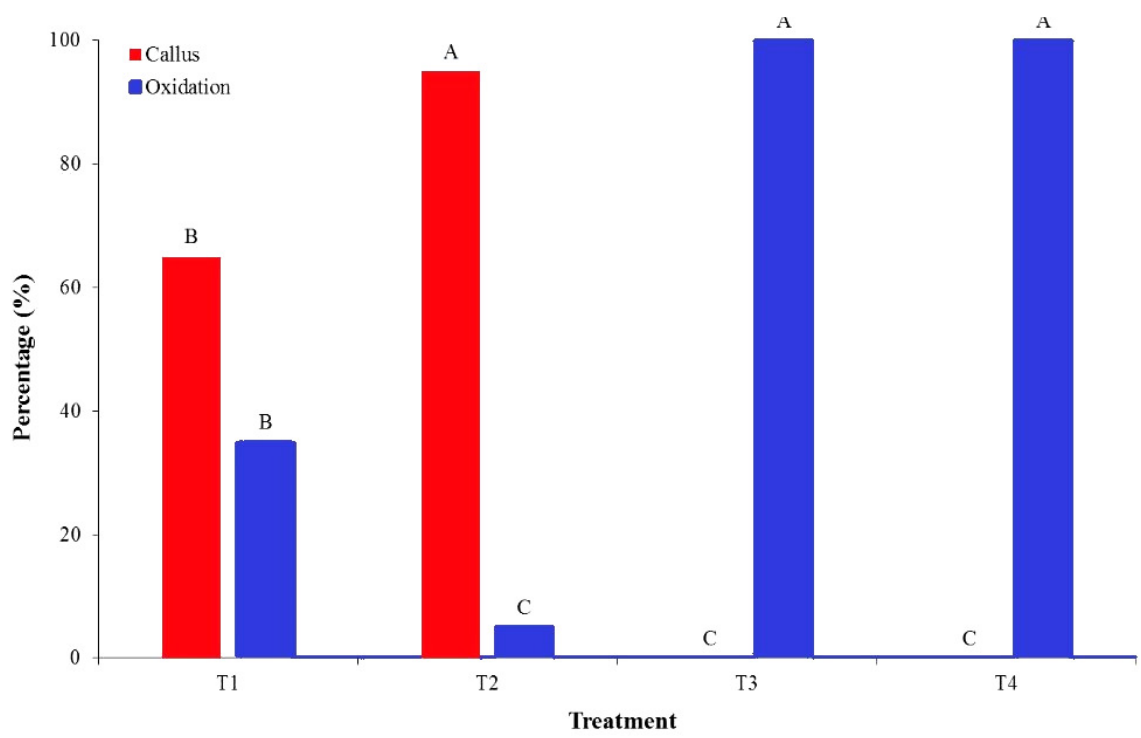

Fig. 3. Percentage callus formation and oxidation for baru leaf explants grown in vitro at different concentrations and combinations of NAA and BAP. Means followed by the same letter do not differ according to Tukey's test at $\mathrm{P}<0.05$. Treatments $\mathrm{T} 1$ to $\mathrm{T} 4$ are explained in Table 2

\section{Discussion}

According to Grattapaglia and Machado (1998), excessive amounts of auxin and sucrose may limit callus formation to the median explant region. However, in this experiment, callus formation occurred across all explants. Silva (2012) observed that the callus area expanded when tissue was treated with 2,4-D (dichlorophenoxyacetic acid).

The auxin and cytokinin ratio directly influences callus formation, whereas higher auxin concentrations lead to the formation of roots. In contrast, higher cytokinin concentrations induce the formation of aerial parts. However, when tissues are cultivated in a culture medium containing both regulators, intermediate stages are found and tissue growth occurs in the form of undifferentiated cells (Taiz and Zeiger, 2013).

Pasqual et al. (1998) reported that auxins are mostly responsible for callus induction and that the effect of cytokinins, which stimulate cell division and control morphogenesis, in tissue culture, is emphasized when applied along with auxins. This was confirmed by the results produced by the present study, where the highest callogenesis rates were recorded when only NAA was applied and when the BAP concentration was the lowest. This result confirmed the balance between the two types of regulators.

Larson (2014) observed that more callus tissue formed on the nodal segments when the NAA concentration was $1.0 \mathrm{mg} \mathrm{L}^{-1} \mathrm{NAA}$ and that callus formation was initiated after 45 days of in vitro incubation. This plant cell totipotency principle suggests that several types of explants can be used. However, in practice, some tissue types have a higher proportion of meristematic tissue, which means that they have a greater differentiation capacity (Torres et al.,
1998). This explains why nodal segments generally perform better than other explants.

The same author also recorded lower contamination rates in baru leaf explants when in vitro germinated seeds were compared. The results showed that each type of explant possesses different susceptibilities to contamination by microorganisms. This means that it is important to develop protocols for each stage of the micropropagation process so that quality regenerated plants can be obtained.

There was still considerable contamination by microorganisms growth in the hereby experiment, irrespective of the contamination results for each treatment. Therefore, the protocol proposed here was not particularly effective at preventing microorganism growth. However, this contamination, which was mostly due to fungi, did not prevent callus formation and did not lead to pathogenic symptoms. Chaibub et al. (2009) reported a similar contamination situation when cultivating $D$. alata almonds in vitro. They concluded that the fungi causing the contamination were endophytic species.

Controlling tissue contamination is inherent to the success of in vitro explant establishment. Therefore, the preservation of explant integrity should be taken into account when developing callus induction methodologies. In particular, attention should be paid to plant hormone concentrations and cultivation techniques (Dutra et al., 2009).

There was no phenolic oxidation observed in the present study. Larson (2014) also reported the same results. This suggests that the use of ascorbic acid $\left(100 \mathrm{mg} \mathrm{L}^{-1}\right)$ efficiently controlled oxidation. It is already known that ascorbic acid has antioxidant activity and can absorb phenolic compounds during in vitro propagation. Therefore, it is frequently used in many different protocols. 
542

Soares et al. (2007) suggested that callus formation is very common in woody species. The NAA regulator affects cell differentiation (Taiz and Zeiger, 2013). The cytokinins, in turn, play an important role in meristematic function, which induces callus formation (Werner and Schmüulling, 2009; Buechel et al., 2010; Su et al., 2011). They may have positively affected the baru leaf explant results.

During the first phase of the experiment, callus formation occurred even in the treatment without cytokinin addition, which suggested that baru contains high endogenous concentrations of this regulator. However, when BAP was added, the callus percentage increased. The results suggest that $2.0 \mathrm{mg} \mathrm{L}^{-1}$ of NAA, combined with 2.5 $\mathrm{mg} \mathrm{L}^{-1}$ of BAP, was the most viable regulator ratio for the development of baru leaf explants. According to Bray et al. (2000), oxidation is caused by the release of phenolic compounds in vitro, by tissue injury, or by the senescence of tropical native species that contain high levels of these compounds.

One of the roles played by cytokinins during plant adaptation to stress is to serve as a protective agent when there is excess of light, which causes the inhibition of photosystem II and the synthesis of reactive oxygen species (ROS). These, in turn, can degradate protein D1. Cytokinin is part of the antioxidant system and is involved in the repair of protein D1 (Cortleven et al., 2014). However, the higher the BAP concentration added to the culture medium, the higher the oxidation rate. Oliveira et al. (2016) reported a similar result when they studied mangaba (Hancornia speciosa Gomes) and suggested that it was due to the toxic effect of the regulator when the BAP concentration was too high. Such a toxic effect then negatively affected the development of the explant and probably led to its degradation. Therefore, the endogenous concentrations of the regulator can negatively affect explant growth at high concentrations. This means that the use of substances such as ascorbic acid, which has an antioxidant role, may positively influence the growth and development of some explants, but in this experiment, the dosage used was not high enough and its effect was suppressed by the toxic BAP concentrations.

The disinfection methodology used in the second phase of the experiment was the same as the one used in the first phase. The absence of phenolic oxidation could be due to the absence or the reduced presence of endogenous inocula and the reduced susceptibility of the leaf segment compared to the other explant types, because in the first stage, the leaf segments had the lowest contamination percentages.

\section{Conclusions}

Baru (Dipteryx alata Vog.) micropropagation could be successfully performed and considerable callus development was observed. However, the different responses of each explant type must be taken into account, particularly in terms of the growth regulators concentrations applied and their effects on tissue contamination and oxidation levels. The results from the present study suggest that $2.0 \mathrm{mg} \mathrm{L}^{-1}$ NAA can be used for callogenesis within nodal explants and $2.0 \mathrm{mg} \mathrm{L}^{-1} \mathrm{NAA}$ combined with $2.5 \mathrm{mg} \mathrm{L}^{-1} \mathrm{BAP}$ can be used for baru leaf explants.

\section{References}

Arakaki AH, Scheidt GN, Portella AC, Arruda EJ, Costa RB (2009). O baru (Dipteryx alata Vog) como alternativa de sustentabilidade em área de fragmento florestal do Cerrado, no Mato Grosso do Sul [The baru (Dipteryx alata Vog) as a sustainability alternative in a forest fragment area of the Cerrado, in Mato Grosso do Sul]. Interações (Campo Grande) 10(1):31-39.

Araruna EC, Oliveira JPR, Pereira VJ, Asmar SA, Melo B (2017). Salt concentrations in culture media for the development of Dipteryx alata in vitro. Pesquisa Agropecuaria Brasileira 52(12):1295-1300.

Bray E, Bailey-Serres J, Weretilnyk E (2000). Responses to abiotic stresses. In: Buchanan B, Gruissem W, Jones R (Eds). Biochemistry and molecular biology of plants. American Society of Plant Physiologists, Maryland pp 1158-1203.

Buechel S, Leibfried A, To JP, Zhao Z, Andersen SU, Kieber JJ, Lohmann JU (2010). Role of A-type Arabidopsis response regulators in meristem maintenance and regeneration. European Journal of Cell Biology 89(23):279-284.

Candil RFM, Arruda EJ, Arakaki AH (2007). O Cumbaru (Dipteryx alata Vog), o desenvolvimento local e a sustentabilidade biológica no assentamento Andalucia, Nioaque/MS [The Cumbaru (Dipteryx alata Vog), local development and the biological sustainability in the Andalucia Settling, Nioaque/MS]. Interações (Campo Grande) 8(1):75-80.

Chaibub AA, Sena APA, Mesquita FL, Maeshima FHS, Oliveira SA, Faria PR, Sibov ST, Araújo LG (2016). Fungos endofiticos associados às amêndoas do baru (Dipteryx alata Vog.) durante a germinação e multiplicação in vitro [Endophytic fungi associated with baru (Dipteryx alata Vog) almonds during in vitro germination and multiplication]. Conpeex. Retrieved 2016 June 07 from http: //www. ufgbr/conpeex/2009.

Cortleven A, NitschkeS, Klaumünzer M, Abdelgawad H, Asard H, Grimm B, Riefler M, Schmülling T (2014). A novel protective function for cytokinin in the light stress response is mediated by the AHK2 and AHK3 receptors. Plant Physiology 164:1470-1483.

Dutra LF, Wendling I, Brondani GE (2009). A micropropagação de eucalipto [The eucalyptus micropropagation]. Pesquisa Florestal Brasileira 58:49-59.

Eldessoky DS, Ismail RM, Hadi-Abdel A, Abdallah NA (2014). Establishment of regeneration and transformation system of sugarcane cultivar GT549(C9). GMCrops 2(2):126-134.

Ferreira DF (2011). SISVAR (Sistema para análise de variância [Variance Analysis System]). Federal University of Lavras (Sciences Exact Departament-DEX).(CD-ROM).

Fetzer DL, Cruz PN, Hamerski F, Corazza ML (2018). Extraction of baru (Dipteryx alata vogel) seed oil using compressed solvents technology. The Journal of Supercritical Fluids 137:23-33.

Grattapagia D, Machado MA (1998). Micropropagação [Micropropagation]. In: Torres AC, Caldas LS, Buso JA (Eds). Cultura de tecidos e transformação genética de plantas [Tissue culture and genetic transformation of plants]. Embrapa-SPI/Embrapa-CNPH, Brasilia pp 183-260. 
Larson LCRS (2014). Estratégias de propagação de barueiro (Dipteryx alata Vog.) e jatobazeiro do cerrado (Hymenaea stigonocarpa MART.) [Baru propagation strategies (Dipteryx alata Vog) and jatobas of the Cerrado (Hymenaea stigonocarpa MART.). PhD Thesis, Paulista State University.

Lemos MRB, Siqueira EMA, Arruda SF, Zambiazi RC (2012). The effect of roasting on the phenolic compounds and antioxidant potential of baru nuts [Dipteryx alata Vog.]. Food Research International 48(2):592-597.

Lloyd G, McCown B (1980). Commercially feasible micropropagation of montaim laurel, Kalmia latifolia, by use of shoot tip culture. Combined Proceedings 30:421-427.

Lorenzi H (1998). Árvores brasileiras: manual de identificação e cultivo de plantas arbóreas nativas do Brasil [Brazilian trees: identification and cultivation of native tree plants in Brazil]. Plantarum, São Paulo.

Mendonça RC, Felfili JM, Walter BMT, Silva MG Jr, Rezende AV, Filgueiras TS, Nogueira PE, Fagg CW (2008). Flora vascular do bioma Cerrado: checklist com 12.356 espécies [Flora vascular do Bioma Cerrado: Checklist with 12,356 species]. In: Sano SM, Almeida SP, Ribeiro JF (Eds). Cerrado: ecologia e flora [Cerrado: ecology and flora]. Embrapa Cerrados, Planaltina pp 421-1279.

Murashige T, Skoog F (1962). A revised medium for rapid growth and bioassays with tobacco tissue cultures. Physiologia Plantarum 15(3):473497.

Oliveira KS, Freire FAM, Aloufa MAI (2016). Efeito de 6benzilaminopurina e ácido naftalenoacético sobre a propagação in vitro de Hancornia speciosa Gomes [6-benzylaminopurine and naphthaleneacetic acid effect on the in vitro propagation of Hancornia speciosa Gomes]. Floresta 46(3):335-342.

Pasqual M, Ramos JD, Hoffman A, Carvalho GR (1998). Reguladores de crescimento [Growth regulators]. In: Meios de cultura [Culture mediums].UFLA/FAEPE, Lavras, cap. 3 pp 37-84.

Pott A, Pott VJ (2003). Plantas nativas potenciais para sistemas agroflorestais em Mato Grosso do Sul [Potential native plants for agroforestry systems in Mato Grosso do Sul]. In: Seminário sistemas agroflorestais e desenvolvimento sustentável [Seminar on agroforestry systems and sustainable development], Embrapa Gado de Corte, Campo Grande, CD-ROM. Retrieved 2018 March 07 from http://saf.cnpgcembrapa. br/publicacoes/03.pdf.
Schuch MW, Erig AC (2005). Micropropagação e plantas frutíferas [Micropropagation and fruit plants]. In: Fachinello JC, Hoffmann A, Nachtigal JC (Eds). Propagação de plantas frutíferas [Fruits plants propagation].Embrapa, Brasíliapp 155-173.

Silva HFJ, Asmar SA, Oliveira RC, Luz JMQ, Melo B (2016). Alternative supplements and MS medium concentrations in the in vitro establishment of Dipteryx alata VOG. Bioscience Journal 32(5):11381146.

Silva LC (2012). Germinação, estabelecimento e multiplicação in vitro de Eugenia dysenterica DC. e Dipteryx alata Vogel, espécies frutiferas do Cerrado [Germination, establishment and in vitro multiplication of Eugenia dysenterica DC. and Dipteryx alata Vogel, fruit species of the Cerrado].MSc Dissertation, Federal University of Goiás.

Soares FP, Paiva R, Alvarenga AA, Nogueira RC, Emrich EB, Martinotto C (2007). Organogênese direta em explantes caulinares de mangabeira (Hancornia speciosa Gomes) [Direct organogenesis in mangabeira stem explants (Hancornia speciosa Gomes). Revista Brasileira de Biociencias 5(S2):723-725.

Su YH, Liu YB, Zhang XS (2011). Auxin-cytokinin interaction regulates meristem development. Molecular Plant 4(4):616-625.

Taiz L, Zeiger E (2013). Fisiologia vegetal [Plant Physiology]. Artmed, Porto Alegre.

Torres AC, Caldas LS, Buso JÁ (1998). Cultura de tecidos e transformação genética de plantas [Tissue culture and genetic transformation of plants]. EMBRAPA/CBAB, Brasilia.

Vieira RF, Agostini-Costa TS, Silva DB, Sano SM, Ferreira FR (2016). Espécies alimentícias nativas da região Centro-Oeste [Native species of the Central-West region]. In: Vieira RF, Camillo J, Coradin L (Eds). Espécies nativas da flora brasileira de valor econômico atual ou potencial: Plantas para o futuro: Região Centro-Oeste [Native species of Brazilian flora of current or potential economic value: Plants for the future: Central-West Region].MMA, Braslia pp 107-351.

Werner T, Schmuulling T (2009). Cytokinin action in plant development. Current Opinion in Plant Biology 12(5):527-538. 